\title{
Identification of Eutypa spp. Causing Eutypa Dieback of Grapevine in Eastern North America
}

Philippe E. Rolshausen, Department of Botany and Plant Sciences, University of California, Riverside 92521; Kendra Baumgartner, United States Department of Agriculture-Agricultural Research Service (USDA-ARS), Davis, CA 95616; Renaud Travadon, Department of Plant Pathology, University of California, Davis 95616; Phillip Fujiyoshi, USDA-ARS, Davis; Jérome Pouzoulet, Department of Botany and Plant Sciences, University of California, Riverside; and Wayne F. Wilcox, Department of Plant Pathology and Plant Microbe Biology, Cornell University, Geneva, NY 14456

\begin{abstract}
Rolshausen, P. E., Baumgartner, K., Travadon, R., Fujiyoshi, P., Pouzoulet, J., and Wilcox, W. F. 2014. Identification of Eutypa spp. causing Eutypa dieback of grapevine in eastern North America. Plant Dis. 98:483-491.

Eutypa dieback of grapevine is caused by Eutypa lata in production areas with Mediterranean climates in California, Australasia, Europe, and South Africa. Eutypa dieback has also been described in the colder, eastern North American vineyards where cultivars adapted from native Vitis spp. (e.g., Vitis $\times$ labruscana 'Concord') are primarily grown. However, the causal agents associated with the diseases in this region have not been conclusively identified. Examination of 48 vineyards showing symptoms of dieback in the northeastern United States (Connecticut, Massachusetts, Michigan, New York, Ohio, and Rhode Island) and Ontario, Canada revealed that vineyards were mainly infected by Eutypa spp. other than E. lata. Multigene phylogenies (inter-

nal transcribed spacer ribosomal DNA, $\beta$-tubulin, and RNA polymerase II) of isolates recovered from these vineyards indicated that Eutypa dieback is caused primarily by an undescribed Eutypa sp. and E. laevata. Eutypa sp. was recovered from $56 \%$ of the vineyards examined, whereas E. laevata and E. lata were less far common (17 and 6\%, respectively). Fruiting body morphology and spore dimensions supported phylogenetic separation of the three taxa. Pathogenicity tests conducted on Vitis vinifera 'Chardonnay' in the greenhouse and in the field verified that all three species were able to cause wood canker and to infect pruning wounds, respectively.
\end{abstract}

Eutypa lata (Pers.) Tul. \& C. Tul. (syn. E. armeniacae Hansf. \& M.V. Carter) (Ascomycota: Diatrypaceae) is the primary causal agent of Eutypa dieback. The fungus has been reported from at least 90 plant species within 52 genera and 28 families $(5,9,43)$. Eutypa dieback is a major wood canker disease of perennial agricultural crops, including grapevines (Vitis spp.). The chronic infections of the wood leads to cumulative yield losses that significantly diminish vineyard longevity $(20,35)$.

E. lata causes a soft rot of the vascular system by producing an array of cell-wall-degrading enzymes, and its phytotoxic secondary metabolites translocate to the herbaceous parts of the plants, where they cause characteristic stunting and deformation of the foliage $(16,21,27)$. Several years following an initial wound infection, a wood canker develops and dieback becomes apparent as spurs, canes, and portions of cordon die. E. lata commonly infects wounds during the dormant season, when rain initiates ascospore release and when grapevines are pruned. In many regions, infection can be minimized by delaying pruning until late winter or early spring, when pruning wounds are less susceptible and ascospore discharge is low, coupled with application of a protective fungicide (e.g., thiophanate methyl) or boron to pruning wounds $(28,31,47)$. However, once a grapevine is infected, there are no curative treatments other than pruning and removal of symptomatic wood.

E. lata has been identified as the causal agent of Eutypa dieback in major grape-production regions where Vitis vinifera (e.g., 'Chardonnay') is grown, including California, Europe, South Africa, and Australasia $(8,29,39)$. These regions, with primarily a Mediterranean climate, have been extensively surveyed for Eutypa dieback. The causal agent's identity has been determined through morpho-

Corresponding author: P. E. Rolshausen, E-mail: philrols@ucr.edu

Accepted for publication 21 October 2013.

http://dx.doi.org/10.1094/PDIS-08-13-0883-RE

(C) 2014 The American Phytopathological Society logical and molecular methods, and the susceptibility of $V$. vinifera to the pathogen has been well documented $(23,29,39,40,43)$. Within these regions, reports of E. lata are restricted to locations with annual precipitation of at least $3.5 \mathrm{~cm}$ (8). In California, for example, E. lata is the predominant cause of canker and dieback of grapevines in the northern and coastal regions but is less common than other wood-canker pathogens in the dryer and hotter southern and central areas of the state $(43,46)$. Symptoms of Eutypa dieback have also been described from grape-growing regions of eastern North America, specifically the states of New York and Michigan and Ontario, Canada $(10,17,22,41)$. In contrast with the Mediterranean climate, cold-tolerant cultivars derived from native Vitis spp. (e.g., Vitis $\times$ labruscana 'Concord') and Vitis interspecific hybrids (e.g., 'Vidal blanc') historically have predominated in these areas, although $V$. vinifera is cultivated in the warmer mesoclimates (e.g., near the Great Lakes and the Atlantic Ocean). The northeastern United States encompasses several relatively nascent grape-growing regions, and there has not been a definite investigation of the pathogen species causing Eutypa dieback in these regions.

In addition to $E$. lata, 15 Diatrypaceous species are reported from grapevine worldwide: E. leptoplaca, Cryptosphaeria pullmanensis, Cryptovalsa ampelina, C. rabenhortsii, Diatrype sp., Diatrype oregonensis, D. stigma, D. whitmanensis, D. vulgaris, Diatrypella verrucaeformis, Eutypella vitis, E. leprosa, E. citricola, E. microtheca, and E. scoparia $(7,10,19,29,42,44,45)$. Our preliminary analyses, based on phylogenetic reconstruction of the internal transcribed spacer (ITS) ribosomal (r)DNA region and microsatellite genotyping (2) of a few Eutypa isolates recovered from grapevine, suggested that Eutypa spp. other than Eutypa lata were the main causal agents of Eutypa dieback in the northeastern United States (26). Identification of Eutypa spp. is confounded by discordance between the current morphological taxonomy of the Diatrypaceae family and phylogenetic analyses $(1,44)$, as well as an unresolved species concept for $E$. lata. Indeed, phylogenetic analyses of $E$. lata neotypes from Europe, E. lata isolates from several grape-growing regions around the world, and type specimens of other taxa within the Diatrypaceae family revealed a high 
level of intraspecific variability (29) that did not support Rappaz's taxonomical classification of E. lata (25). The geographic distributions, host ranges, and pathogenicity of the Diatrypaceous taxa reported from grapevine are still fragmented; thus, it remains unclear which species are causal agents of Eutypa dieback and which are merely weak parasites or saprophytes.

The goal of this study was to identify the causal agents of Eutypa dieback of grapevine in eastern North America. To address this goal, we used a combination of multigene phylogenies (ITS rDNA, $\beta$-tubulin, and RNA polymerase II subunit II [RPB2]) and microsatellite genotyping of both Eutypa type specimens and a large number of isolates recovered from diseased vineyards in the northeastern United States and southeastern Canada. In addition, we examined the morphological characteristics of eastern Eutypa isolates and of fruiting bodies found on grapevines. Finally, we tested the pathogenicity of a subsample of Eutypa isolates on grapevine in greenhouse and field trials.

\section{Materials and Methods}

Grapevine sampling and fungal isolation. The largest grapeproduction region east of the Rocky Mountains is located near the Great Lakes and, therefore, our field sites were located primarily in New York (NY), Ohio (OH), Michigan (MI), and the Canadian province of Ontario $(\mathrm{ON})$. We also established field sites in the New England states of Connecticut (CT), Massachusetts (MA), and Rhode Island (RI), which represent a smaller production region composed of relatively young vineyards yet are similar in climate to the former. Vineyards from 2 to 35 years old were selected on the basis of the presence of dieback symptoms (dead spurs, stunting and death of green shoots, or dwarfed leaves with tattered margins) and wood cankers in the spurs, cordons, or trunks. We collected wood cankers from a total of 623 vines among 48 vineyards. Fungal isolates were recovered on potato dextrose agar (PDA; Difco Laboratories) amended with tetracycline (100 ppm) from wood cankers by surface sterilizing wood chips (approximately 3 by 3 by $3 \mathrm{~mm}$ in size). Wood samples were disinfested in $10 \%$ bleach (sodium hypochlorite) for $2 \mathrm{~min}$ and rinsed twice in distilled water for 2 min. After 2 weeks of growth at room temperature in the dark, fungal isolates with culture morphology typical of Eutypa spp. were hyphal tip purified to PDA. We recovered a total of 112 Eutypa isolates from the wood samples, from which 80 isolates representing all the vineyards sites were kept in our collection for further analyses.

Upon identification of Eutypa dieback from the collected wood samples, we collected three Eutypa sp. fruiting bodies, specifically from a Chardonnay vineyard in Geneva, NY. As morphological and molecular comparisons, we also collected three E. lata stromas from a commercial Chardonnay vineyard in Sonoma, CA. Ascospores were harvested from perithecial stromas as described by Carter (8) and resuspended in $5 \mathrm{ml}$ of sterile water. To obtain single ascospore isolates, an aliquot of $20 \mu \mathrm{l}$ was pipetted on PDA amended with tetracycline $(100 \mathrm{ppm})$. After 7 days of growth at room temperature, plates were examined at $\times 5$ under the dissecting scope for hyphal tips, which were subsequently transferred with a sterile scalpel to PDA. In total, three Eutypa sp. isolates (i.e., SP4CH and SP9HY from New York and UCR-EL38 from California) were selected for phylogenetic analyses (Table 1).

Phylogenetic analyses. DNA was extracted from aerial mycelium scraped from the surface of 14-day-old cultures grown at room temperature (DNeasy Plant kit; Qiagen), following the manufacturer's instructions. The nuclear loci rDNA ITS, $\beta$-tubulin gene, and RPB2 gene were amplified using polymerase chain reaction (PCR) primers ITS1 and ITS4 (48), $\beta \mathrm{t} 2 \mathrm{a}$ and $\beta \mathrm{t} 2 \mathrm{~b}$ (12), and RPB27f and RPB2-11aR (15), respectively. PCR was performed with cycling parameters of 1 cycle at $94^{\circ} \mathrm{C}$ for $5 \mathrm{~min} ; 35$ cycles at $94^{\circ} \mathrm{C}$ for $1 \mathrm{~min}, 58^{\circ} \mathrm{C}$ for $1 \mathrm{~min}$, and $72^{\circ} \mathrm{C}$ for $1.5 \mathrm{~min}$; and a final elongation step at $72^{\circ} \mathrm{C}$ for $5 \mathrm{~min}$. PCR products were sequenced in both forward and reverse directions (Genomic Core Sequencing Facility, University of California, Riverside). BLASTn searches of GenBank identified homologous sequences with high identity.
Extended contiguous sequences obtained by joining overlapping forward and reverse sequences were edited manually (Sequencher v. 4.1; Gene Codes Corporation) and aligned with Clustal W (Geneious v. 6.1.6; Biomatters Ltd.). For comparison, we included type specimens of closely related Eutypa spp. (i.e., belonging to monophyletic group 3) (29): neotypes of E. leptoplaca, E. petrakii var. petrakii, E. lata var. aceri, E. laevata, and E. lata (all originally collected by Rappaz; 25) and voucher specimens of $E$. lata and E. laevata (4,43; Table 1). E. leptoplaca was used as an outgroup for the phylogenetic analysis of the ITS rDNA region. Phylogenetic analysis of the combined loci (ITS, $\beta$-tubulin, and RPB2) was not rooted. Phylogenetic analyses were conducted in MEGA5 (v.5.2.1; The Biodesign Institute) (38). The evolutionary history was inferred using the neighbor-joining method (33). Evolutionary distances were computed using the Tamura-Nei method (37) and were presented in the units of the number of base substitutions per site. All positions containing gaps and missing data were eliminated from the dataset. Bootstrap values were inferred from 1,000 replicates (11). The phylogenetic tree for the ITS rDNA region included all northeastern Eutypa isolates from our collection (i.e., 80 isolates recovered from cankers and the 2 isolates from ascospores). However, for clarity, we showed only 37 representative isolates (Table 1). All isolates of our collection were also genotyped with $E$. lata-specific microsatellite markers (2).

Morphology. Morphological characteristics were examined among six perithecial stromas collected from six different Chardonnay grapevines (i.e., three from New York and three from California). A section of the perithecial stroma was cut in half with a sterile scalpel and the width of 20 perithecia per stroma was measured at $\times 2$ with a Leica stereo-microscope (Leica M165C) using LAS analysis software (v. 4.2; Leica Microsystems Inc.). In addition, the length of 40 ascospores per stroma was measured at $\times 100$ with a Leica microscope (DM4000) using LAS analysis software. All measurements were repeated twice.

Conidia length was measured on a subset of 12 Eutypa isolates (UCR-EL1, M14, RICRSK1, RICFSK1, NYAR2, NYRT2, NYVG2, ONR1, NYCC1, NYCS1, NYDW2, and CTMF1), with four isolates representing each of the three Eutypa spp. (Table 2). To induce sporulation, fungal isolates were incubated on PDA in the dark at room temperature until conidiomata appeared. Forty conidia per isolate from two different plates were measured at $\times 100$. Conidia measurements reflected the curved shape of the spore. For comparison of known species, conidia lengths were compared with those of E. lata and E. laevata type specimens (CBS208.87 and CBS291.87, respectively) and voucher specimens (DCA900 and DSA600, respectively) published by Rappaz (25), Rolshausen et al. (29), and Trouillas and Gubler (43), and the published values were used for comparison.

Pathogenicity tests. The pathogenicity assay in the greenhouse was performed on a subset of nine isolates (M14, RICRSK1, RICFSK1, NYAR2, NYRT2, NYVG2, NYCC1, NYCS1, and NYDW2) representing the three Eutypa spp. identified by phylogenetic analyses. The inoculum consisted of mycelial fragments obtained from potato dextrose broth (Difco Laboratories) cultures, as previously described (40). The final concentration of inoculum was adjusted with sterile water to $1 \times 10^{6}$ fragments $\mathrm{ml}^{-1}$. Mycelium was used because Eutypa conidia are not infectious (8).

In the greenhouse, we inoculated rooted cuttings of $V$. vinifera Chardonnay with each of the nine isolates. Plants were propagated from dormant, two-node cuttings that were callused at $30^{\circ} \mathrm{C}$ and $100 \%$ relative humidity for 12 to 16 days in a mixture of sterile perlite and vermiculite $(1: 1, \mathrm{vol} / \mathrm{vol})$ and then rooted in sterile potting mix. A power drill was used to make a hole $(1.98 \mathrm{~mm}$ in width by $3 \mathrm{~mm}$ in depth) in the woody stems of rooted cuttings at a point approximately $3 \mathrm{~cm}$ below the uppermost node. Plants were inoculated by pipetting $20 \mu \mathrm{l}$ of the mycelial suspension into the drilled hole, then sealing this inoculation site with Vaseline (Unilever) and Parafilm (American National Can) to prevent desiccation of the inoculum. Noninoculated controls were mock inoculated with 20 $\mu \mathrm{l}$ of sterile water. In total, 15 plants were inoculated with each 
Eutypa isolate and the experiment was repeated in two separate greenhouses. Plants were arranged in a completely randomized design with two blocks corresponding to the two greenhouses located at the University of California Experimental Station in Davis.
The conditions set in the greenhouses were a natural sunlight photoperiod with $25 \pm 1^{\circ} \mathrm{C}$ during the day and $18 \pm 3^{\circ} \mathrm{C}$ at night, and plants were hand watered every 3 days. Pathogenicity was evaluated at 11 months post inoculation, based on the length of wood

Table 1. Eutypa isolates collected from six northeastern U.S. states (New York, Ohio, Michigan, Connecticut, Rhode Island, and Massachusetts) and one province of southeastern Canada (Ontario), and related Eutypa taxa that formed the basis for phylogenetic analyses

\begin{tabular}{|c|c|c|c|c|c|c|c|}
\hline \multirow[b]{2}{*}{ Species } & \multirow[b]{2}{*}{ Isolate } & \multirow[b]{2}{*}{ Host } & \multirow[b]{2}{*}{ Collector } & \multirow[b]{2}{*}{ Origin } & \multicolumn{3}{|c|}{ GenBank accession numbers ${ }^{z}$} \\
\hline & & & & & ITS & $\beta$ tubulin & RPB2 \\
\hline Eutypa leptoplaca & CBS 287.87 & Frangula alnus & F. Rappaz & Switzerland & DQ006924 & & \\
\hline E. petrakii var. petrakii & CBS 244.87 & Prunus spinosa & F. Rappaz & Switzerland & AJ302455 & DQ006958 & HM164803 \\
\hline E. petrakii var. petrakii & CBS 245.87 & Salix borealis & F. Rappaz & Norway & AJ302456 & DQ006971 & KF453586 \\
\hline E. laevata & DSA600 & Salix lasiolepis & F. P. Trouillas & California & HM164738 & $\ldots$ & $\ldots$ \\
\hline E. laevata & CBS 291.87 & Salix sp. & F. Rappaz & Switzerland & AJ302449 & DQ006962 & HM164805 \\
\hline E. laevata & ONR1 & Vitis vinifera 'Riesling' & P. E. Rolshausen & Ontario & KF453546 & KF453518 & KF453587 \\
\hline E. laevata & ONMF5 & Vitis hybrid 'Marechal Foch' & P. E. Rolshausen & Ontario & KF453547 & KF453519 & KF453588 \\
\hline E. laevata & OHCS1 & V. vinifera 'Cabernet Sauvignon' & P. E. Rolshausen & Ohio & KF453548 & KF453520 & KF453589 \\
\hline E. laevata & NYAR2 & Vitis hybrid 'Aurore' & P. E. Rolshausen & New York & KF453549 & KF453521 & KF453590 \\
\hline E. laevata & NYRT2 & Vitis hybrid 'Rosette' & P. E. Rolshausen & New York & KF453550 & KF453522 & KF453591 \\
\hline E. laevata & NYVLG1 & V. labrusca & P. E. Rolshausen & New York & KF453551 & KF453523 & KF453592 \\
\hline E. laevata & NYVG2 & Vitis hybrid 'Vignoles' & P. E. Rolshausen & New York & KF453552 & KF453524 & KF453593 \\
\hline E. laevata & NYVCG1 & V. champinii & P. E. Rolshausen & New York & KF453553 & $\ldots$ & $\ldots$ \\
\hline E. lata var. aceri & CBS 290.87 & Acer pseudoplatanus & F. Rappaz & Switzerland & DQ006925 & DQ006965 & HM164804 \\
\hline E. lata var. aceri & CBS 217.87 & Acer campestre & F. Rappaz & France & AJ302451 & DQ006970 & HM164802 \\
\hline E. lata & CBS 289.87 & Cratageus sp. & F. Rappaz & France & DQ006928 & DQ006973 & KF453594 \\
\hline E. lata & CBS 208.87 & Tilia sp. & F. Rappaz & Switzerland & DQ006927 & DQ006969 & KF453595 \\
\hline E. lata & DCA900 & $V$. vinifera & F. P. Trouillas & California & HM164715 & $\ldots$ & $\ldots$ \\
\hline E. lata & RICFSK1 & V. vinifera 'Cabernet Franc' & P. E. Rolshausen & Rhode Island & KF453554 & KF453525 & KF453596 \\
\hline E. lata & RICRSK1 & Vitis hybrid 'Chancelor' & P. E. Rolshausen & Rhode Island & KF453555 & KF453526 & KF453597 \\
\hline E. lata & RICRSK2 & Vitis hybrid 'Chancelor' & P. E. Rolshausen & Rhode Island & KF453556 & KF453527 & KF453598 \\
\hline E. lata & ONCC1 & V. labruscana 'Concord' & P. E. Rolshausen & Ontario & KF453557 & KF453528 & KF453599 \\
\hline E. lata & UCREL1 & V. vinifera 'Cremson' & P. E. Rolshausen & California & KF453558 & KF453529 & KF453600 \\
\hline E. lata & UCREL38 & $V$. vinifera & P. E. Rolshausen & California & KF453559 & KF453530 & KF453601 \\
\hline E. lata & M14 & $V$. vinifera 'Merlot' & P. E. Rolshausen & California & KF453560 & KF453531 & KF453602 \\
\hline Eutypa sp. & DIA3 & Vitis hybrid 'Chancelor' & P. E. Rolshausen & Rhode Island & KF453561 & KF453532 & KF453603 \\
\hline Eutypa sp. & MIMF1 & Vitis hybrid 'Marechal Foch' & P. E. Rolshausen & Michigan & KF453562 & $\ldots$ & $\ldots$ \\
\hline Eutypa sp. & MID1 & Vitis hybrid 'Delaware' & P. E. Rolshausen & Michigan & KF453563 & KF453533 & KF453604 \\
\hline Eutypa sp. & MICH1 & V. vinifera 'Chardonnay' & P. E. Rolshausen & Michigan & KF453564 & KF453534 & KF453605 \\
\hline Eutypa sp. & MASBAF1 & Vitis hybrid 'Seyval Blanc' & P. E. Rolshausen & Massachusetts & KF453565 & $\ldots$ & $\ldots$ \\
\hline Eutypa sp. & MARGWR1 & V. vinifera 'Riesling' & P. E. Rolshausen & Massachusetts & KF453566 & KF453535 & KF453606 \\
\hline Eutypa sp. & EJG E117NY & $V$. vinifera & P. E. Rolshausen & New York & DQ006949 & $\ldots$ & $\ldots$ \\
\hline Eutypa sp. & NYCC1 & V. labruscana 'Concord' & P. E. Rolshausen & New York & KF453567 & KF453536 & KF453607 \\
\hline Eutypa sp. & NYVRG5 & V. rupestris & P. E. Rolshausen & New York & KF453568 & $\ldots$ & \\
\hline Eutypa sp. & NYCSPM2 & V. vinifera 'Cabernet Sauvignon' & P. E. Rolshausen & New York & KF453569 & KF453537 & KF453608 \\
\hline Eutypa sp. & NYCHPA1 & V. vinifera 'Chardonnay' & P. E. Rolshausen & New York & KF453570 & $\ldots$ & $\ldots$ \\
\hline Eutypa sp. & NYSBMD2 & V. vinifera 'Sauvignon Blanc' & P. E. Rolshausen & New York & KF453571 & $\ldots$ & $\ldots$ \\
\hline Eutypa sp. & NYCS1 & V. vinifera 'Cabernet Sauvignon' & P. E. Rolshausen & New York & KF453572 & KF453538 & KF453609 \\
\hline Eutypa sp. & NYDW2 & Vitis hybrid 'Delaware' & P. E. Rolshausen & New York & KF453573 & KF453539 & KF453610 \\
\hline Eutypa sp. & $\mathrm{SP} 4 \mathrm{CH}$ & V. vinifera 'Chardonnay' & P. E. Rolshausen & New York & KF453574 & KF453540 & KF453611 \\
\hline Eutypa sp. & SP9HY & V. labruscana 'Concord' & P. E. Rolshausen & New York & KF453575 & $\ldots$ & $\ldots$ \\
\hline Eutypa sp. & CTCFHK1 & V. vinifera 'Cabernet Franc' & P. E. Rolshausen & Connecticut & KF453576 & KF453541 & KF453612 \\
\hline Eutypa sp. & CTCFJE2 & V. vinifera 'Cabernet Franc' & P. E. Rolshausen & Connecticut & KF453577 & $\ldots$ & $\ldots$ \\
\hline Eutypa sp. & CTMF2 & Vitis hybrid 'Marechal Foch' & P. E. Rolshausen & Connecticut & KF453578 & & $\cdots$ \\
\hline Eutypa sp. & CTSVHK1 & Vitis hybrid 'Seyval Blanc' & P. E. Rolshausen & Connecticut & KF453579 & $\ldots$ & $\ldots$ \\
\hline Eutypa sp. & CTCHJE1 & V. vinifera 'Chardonnay' & P. E. Rolshausen & Connecticut & KF453580 & KF453542 & KF453613 \\
\hline Eutypa sp. & CTCFJE1 & V. vinifera 'Cabernet Franc' & P. E. Rolshausen & Connecticut & KF453581 & & $\ldots$ \\
\hline Eutypa sp. & $\mathrm{OHCC1}$ & V. labruscana 'Concord' & P. E. Rolshausen & Ohio & KF453582 & KF453543 & KF453614 \\
\hline Eutypa sp. & ONMF1 & Vitis hybrid 'Marechal Foch' & P. E. Rolshausen & Ontario & KF453583 & KF453544 & KF453615 \\
\hline Eutypa sp. & ONB2 & Vitis hybrid 'Baco' & P. E. Rolshausen & Ontario & KF453584 & $\ldots$ & $\ldots$ \\
\hline Eutypa sp. & ONS1 & Vitis hybrid 'Seyval Blanc' & P. E. Rolshausen & Ontario & KF453585 & KF453545 & KF453616 \\
\hline
\end{tabular}

${ }^{\mathrm{z}}$ ITS = internal transcribed spacer and RPB2 = RNA polymerase II subunit II.

Table 2. Incidence of Eutypa dieback and Eutypa species recovered from 48 vineyards in six northeastern U.S. states (New York, Ohio, Michigan, Connecticut, Rhode Island, and Massachusetts) and one province of southeastern Canada (Ontario)

\begin{tabular}{lcccccccc}
\hline & \multicolumn{7}{c}{ Number of vineyards per state or province } \\
\cline { 2 - 9 } Incidence $^{\mathbf{z}}$ & $\begin{array}{c}\text { Ontario } \\
(\boldsymbol{n}=\mathbf{9})\end{array}$ & $\begin{array}{c}\text { Michigan } \\
(\boldsymbol{n}=\mathbf{1 3})\end{array}$ & $\begin{array}{c}\text { Ohio } \\
(\boldsymbol{n}=\mathbf{5})\end{array}$ & $\begin{array}{c}\text { New York } \\
(\boldsymbol{n}=\mathbf{1 1})\end{array}$ & $\begin{array}{c}\text { Connecticut } \\
(\boldsymbol{n}=\mathbf{5})\end{array}$ & $\begin{array}{c}\text { Massachusetts } \\
(\boldsymbol{n}=\mathbf{3})\end{array}$ & $\begin{array}{c}\text { Rhode Island } \\
(\boldsymbol{n}=\mathbf{2})\end{array}$ & $\begin{array}{c}\text { Total } \\
(\boldsymbol{n}=\mathbf{4 8})\end{array}$ \\
\hline Eutypa dieback & 7 & 3 & 3 & 10 & 5 & 2 & 1 & $31(65 \%)$ \\
Eutypa lata & 2 & 0 & 0 & 0 & 0 & 0 & 1 & $3(6 \%)$ \\
E. laevata & 5 & 0 & 1 & 2 & 0 & 0 & 0 & $8(17 \%)$ \\
Eutypa sp. & 4 & 3 & 2 & 10 & 5 & 2 & 1 & $27(56 \%)$ \\
\hline
\end{tabular}

${ }^{\mathrm{z}}$ Incidence is calculated as the number of vineyards with symptoms of Eutypa dieback or from which a specific Eutypa sp. was identified out of the total number of vineyards that were examined $(n=48)$. 
lesions (i.e., wood cankers, in longitudinal section) that developed surrounding the inoculation site and positive recovery of the isolate inoculated to the plant. For each plant, measurements were made of the length of discolored wood radiating above and below the inoculation site (i.e., the wood lesion). Recovery attempts were made from the wood at the margin of each lesion. The steps for pathogen recovery were as follows. Green shoots and roots were cut away from the woody stem and discarded, all bark was scraped off the woody stem, the stem was surface sterilized in $1 \%$ sodium hypochlorite for $2 \mathrm{~min}$, and stem length was measured. Subsequently, stems were cut in half longitudinally through the inoculation sites, a caliper was used to measure the lesion length, and four pieces of wood (each approximately 2 by $5 \mathrm{~mm}$ ) were cut with a flamesterilized scalpel from the distal margins of each lesion. Finally, the wood pieces were surface sterilized in $0.6 \%$ sodium hypochlorite ( $\mathrm{pH}$ adjusted to 7.2) for $1 \mathrm{~min}$, rinsed twice in sterile distilled water for $1 \mathrm{~min}$, and plated on PDA amended with tetracycline (100 ppm).

Analyses of variance (ANOVAs) were used to determine the effect of isolate on the length of wood discoloration. Lengths of wood discoloration data were subjected to reciprocal square root transformation to satisfy the homogeneity of variance assumption. ANOVAs were performed using the MIXED procedure in SAS, with experiment considered as a random effect. Means were calculated using the LSMEANS procedure. Pairwise mean differences with the control level (noninoculated control) were analyzed using Dunnett's test $(P<0.05)$. Recovery rate was calculated as the percentage of plants from which a pathogen was recovered out of the total number of inoculated plants. To assess the main effect of isolate on recovery rate, generalized linear mixed models were performed using the GLIMMIX procedure in SAS, which utilizes the logit link function to accommodate binomial data. The factor experiment was considered as random effect. Recovery rates of the noninoculated controls (all of which were zero) were excluded from the analyses.

The pathogenicity assay in the field was measured on a subset of eight isolates (RICRSK1, RICFSK1, NYAR2, NYRT2, NYCC1, NYCS1, NYDW2, and NYCSPM2) representing the three Eutypa spp. identified by phylogenetic analyses. We evaluated the ability of the eight isolates to infect dormant pruning wounds, which are the typical infection courts in the disease cycle of Eutypa dieback. Inoculum was prepared as described above (40). Inoculations were conducted in a vineyard located in Geneva, NY. The $V$. vinifera Chardonnay vineyard established in 2004 was trained to bilateral cordons with five to eight three-bud spurs per cordon (10 to 16 spurs per vine). It was pruned near the end of dormancy in April 2009 and 2010, corresponding to the pruning period for $V$. vinifera vineyard in this region. Each pruning wound was inoculated with $30 \mu \mathrm{l}$ of inoculum of a single isolate, either 1 day or 3 weeks after pruning. Control vines were treated with an equal volume of sterile water. Inoculations for these two post-pruning dates were made on opposite cordons of the same vine for each isolate, with four replicate vines per isolate arranged in a complete randomized design. Spurs were collected from the inoculated pruning wounds the following October (6 months post inoculation) and recovery attempts were made from the wood lesions originating from the inoculation site, as previously described. The extent of wood discoloration (i.e., lesion length) was not recorded for pathogenicity tests because this field trial only aimed at evaluating the ability of isolates to colonize pruning wounds. Percent recovery of each isolate was calculated as the percentage of pruning wounds from which an isolate was recovered out of the total number of inoculated pruning wounds per plant, and this was averaged across four replicate plants per isolate (four plants $\times$ five pruning wounds per plant).

The main and interactive effects of isolate, year, and inoculation date on percent recovery were tested separately for each variety, using an ANOVA performed with the GLIMMIX procedure in SAS, which utilizes the logit link function to accommodate binomial data (14). Percent recovery of the noninoculated controls (all of which were zero) and isolates that were not recovered from any inoculated pruning wounds on either inoculation date in either year were excluded from the analysis to avoid convergence problems. For each isolate, the slice option was used within the lsmeans statement to allow comparisons of percent recovery between inoculation dates (i.e., to test whether pruning wounds were similarly susceptible to infection in April and May) within study years when percent recovery for both dates was greater than zero.

\section{Results}

Phylogenetic analyses. There were, in total, 537 and 1,742 nucleotide positions in the ITS and combined loci (ITS, $\beta$-tubulin, and RPB2) datasets, respectively. Phylogenetic reconstructions of both datasets yielded trees with bootstrap values that strongly supported four monophyletic clades, representing three known species (i.e, E. lata, E. lata var. aceri, and E. laevata) and one undescribed Eutypa sp. (Figs. 1 and 2). Results from the phylogenetic analyses were supported by microsatellite profiles generated from $E$. lataspecific microsatellite markers (2), based on positive amplification of all microsatellite loci from isolates of $E$. lata but not from nonE. lata isolates. All nine microsatellite loci gave amplification products with alleles within the known range of sizes (39) for the neotype of $E$. lata (CBS 208.87), voucher specimens of $E$. lata (DCA900), and four isolates from our collection (RICFSK1, RICRSK1, RICRSK2, and ONCC1; data not shown). These four isolates also had high ITS, $\beta$-tubulin, and RPB2 sequence identity to the type and voucher specimens of E. lata (Fig. 2). For the non$E$. lata isolates, only two to five microsatellite loci gave positive amplicons, and these were not consistent among isolates within a species. Similarly, two to five loci gave positive amplicons for the type specimens of E. laevata, E. petrakii var. petrakii, and E. leptoplaca. For both type specimens of E. lata var. aceri, six microsatellite loci gave positive amplicons and it was the same six loci for both type specimens. Isolates NYCC1 and NYCS1 of Eutypa sp. were selected as holotypes and were deposited at the CBS (Centraalbureau voor Schimmelcultures) fungal collection with accession numbers 130289 and 130290 , respectively.

Based on the phylogenetic analyses of our Eutypa isolate collection, we determined that Eutypa dieback was positively diagnosed in 31 of 48 symptomatic vineyards $(65 \%)$. Within these 48 vineyards, incidence was the highest for Eutypa sp. with $56 \%$ (27 of 48 vineyards), followed by E. laevata with $17 \%$ (8 of 48 vineyards) and $E$. lata with 6\% (3 of 48 vineyards) (Table 2). We also isolated other pathogenic fungi known to cause grapevine wood dieback diseases, including species in the Botryosphaeriaceae family, Phaeoacremonium spp., Phaeomoniella chlamydospora, Diaporthe spp., and Cadophora spp. (3,32).

Morphology. Eutypa sp. shared similar anamorphic and teleomorphic characteristics with those of E. lata neotype (25). For example, the stroma was black, spread out on the surface of the wood, and had round to conical ostioles; perithecia were compact in rows (Fig. 3); and conidia were 21 to $39 \mu \mathrm{m}$ in length (Table 3). In contrast, perithecia of Eutypa sp. appeared embedded superficially in the stroma and sometimes were in contact with each other (Fig. 3). Perithecia of Eutypa sp. were also smaller in size (i.e., 317 $\pm 51 \mu \mathrm{m}$ for Eutypa sp. versus $554 \pm 79 \mu \mathrm{m}$ for $E$. lata) and bore shorter ascospores (i.e., $7.1 \pm 1.2 \mu \mathrm{m}$ for Eutypa sp. versus $9.3 \pm$ $1.1 \mu \mathrm{m}$ for $E$. lata). Interestingly, these features resembled those of the description of the E. laevata neotype (25). Unfortunately, because we did not find the perithecial stroma among vines from which we recovered E. laevata, we could not cross reference the neotype description and compare morphological measurements with those of E. lata and Eutypa sp. teleomorphs. Nonetheless, we were able to measure the conidia. The mean conidial length of $E$. laevata isolates was longer than those of E. lata and Eutypa sp. (Table 3; Fig. 3), which supports previous reports $(25,43)$. Noticeably, only two E. laevata isolates out of the four selected sporulated in cultures and those which sporulated produced fewer number of pycnidia than the E. lata and Eutypa sp. isolates.

Pathogenicity tests. Eleven months after inoculation, plants inoculated with isolates of Eutypa sp. (NYCC1 and NYCS1), E. laevata (NYAR2 and NYRT2), and E. lata (M14, RICRSK1, and 
RICFSK1) had significantly longer lesions than the noninoculated controls $(P<0.05)$, suggesting that these isolates were pathogenic (Table 4). Mean lesion lengths of plants inoculated with Eutypa sp. NYDW2 and E. laevata NYVG2 were not statistically different than that of the control, even if they were longer. The mean lesion length ranged from $7.2 \mathrm{~mm}$ for the control to $27.2 \mathrm{~mm}$ for E. lata M14. Percent recovery of all the Eutypa isolates was 56 to $87 \%$ and was not statistically different among isolates $(P=0.05)$.

Recovery of isolates from inoculated pruning wounds showed that isolates of Eutypa sp. (NYCCI, NYCSPM2, NYCS1, and NYDW2), E. laevata (NYAR2 and NYRT2), and E. lata
(RICFSK1 and RICRSK1) were able to infect dormant Chardonnay under field conditions (Table 5). Percent recovery was much lower than in the preliminary greenhouse experiment, ranging from 0 to $23 \%$. This low percent recovery of isolates in our field trials was consistent with past observations, in which mycelium rather than ascospores (the natural form of inoculum in the field) where used as inoculum. Both isolates of $E$. lata (RICFSK1 and RICRSK1) and one isolate of Eutypa sp. (NYDW2) were consistently recovered from pruning wounds inoculated on both inoculation dates and in both years. ANOVAs showed that there were no significant differences in percent recovery among isolates $(P=$

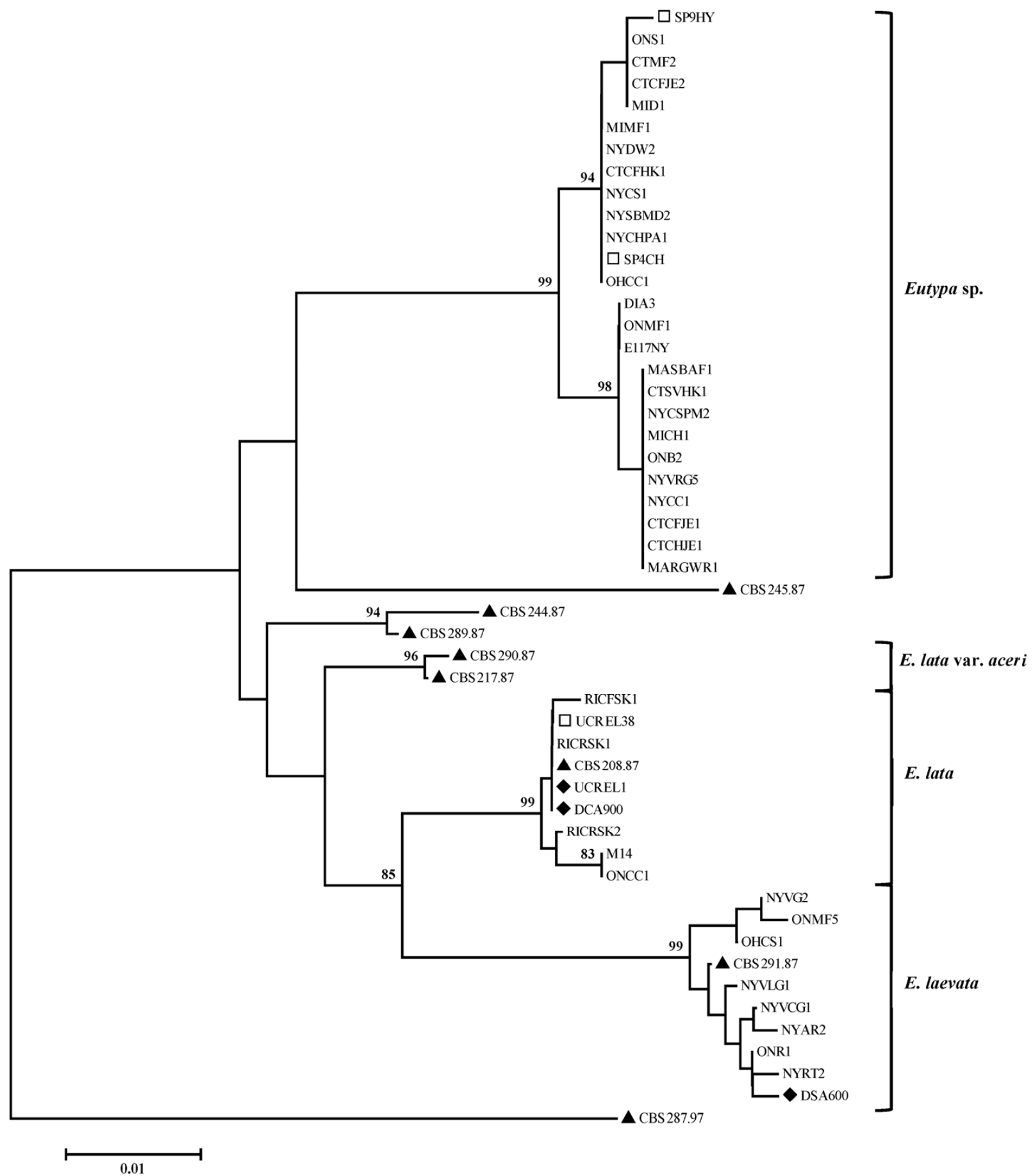

Fig. 1. Evolutionary relationships of Eutypa specimens based on internal transcribed spacer ribosomal DNA sequence data using the neighbor-joining statistical method. The optimal tree with the sum of branch length $=0.23$ is shown. Evolutionary distances were computed using the Tamura-Nei method and are in the units of the number of base substitutions per site. Bootstrap values were inferred from 1,000 replicates and are shown above their corresponding branches. Eutypa leptoplaca was used as the outgroup. Fungal isolates are identified with their isolate number. Filled triangles represent type specimens, filled diamonds represent voucher specimens, and open squares represent specimens collected from perithecial stroma. Other specimens were isolated from wood cankers. 
0.95 and 0.81 , respectively), between inoculation dates $(P=0.12$ and 0.08 , respectively), between years $(P=0.12$ and 0.59 , respectively), or due to the various interactive effects (all $P>0.36$, all $P$ $>0.48$, respectively). Our finding of no significant differences between inoculation dates over the course of 2 years suggested that pruning wounds remained as susceptible at 3 weeks post pruning as they were on the day of pruning.

\section{Discussion}

E. lata is the primary causal agent of Eutypa dieback in vineyards grown in Mediterranean climates (39). However, our results clearly indicate that grapevines with symptoms of Eutypa dieback in the northeastern United States and southeastern Canada are colonized primarily by species other than $E$. lata. Our findings show that E. laevata and Eutypa sp. are newly recognized as grapevine pathogens. These species are indeed pathogenic, based on results of inoculations conducted in both the greenhouse and the field. These results extend the host range of E. laevata from Salix sp. to Vitis spp. and expand the list of Diatrypaceous fungi associated with grapevine.

Our phylogenetic analyses and microsatellite genotyping improve the species delineation of closely related Eutypa taxa, which

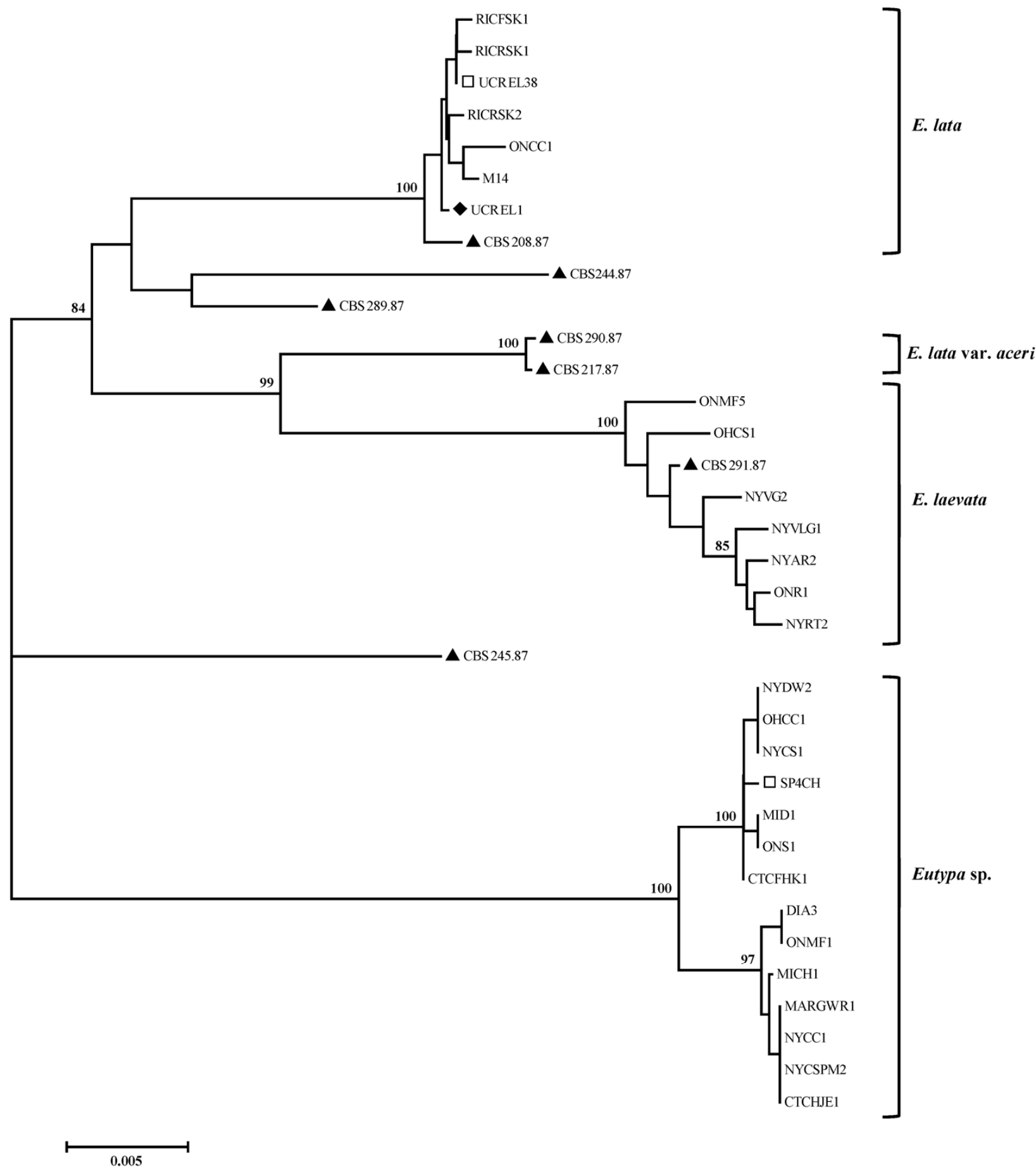

Fig. 2. Evolutionary relationships of Eutypa specimens based on internal transcribed spacer, $\beta$-tubulin, and RNA polymerase II sequence data, using the neighbor-joining statistical method. The optimal tree with the sum of branch length $=0.15$ is shown. Evolutionary distances were computed using the Tamura-Nei method and are in the units of the number of base substitutions per site. Bootstrap values were inferred from 1,000 replicates and are shown above the branches. Fungal isolates are identified with their isolate number. Filled triangles represent type specimens, filled diamonds represent voucher specimens, and open squares represent specimens collected from perithecial stroma. Other specimens were isolated from wood cankers. 
were clustered in a monophyletic clade referred to as "group 3" by Rolshausen et al. (29) and "group 6" by Acero et al. (1). Within this clade, the separation of four species (E. lata, E. laevata, E. lata var. aceri, and Eutypa sp.) is strongly supported. Our findings further clarify the species concept of $E$. lata. In this regard, only neotype CBS 208.87 should be viewed as an E. lata type specimen, whereas isolate CBS 289.87 should be renamed as something other
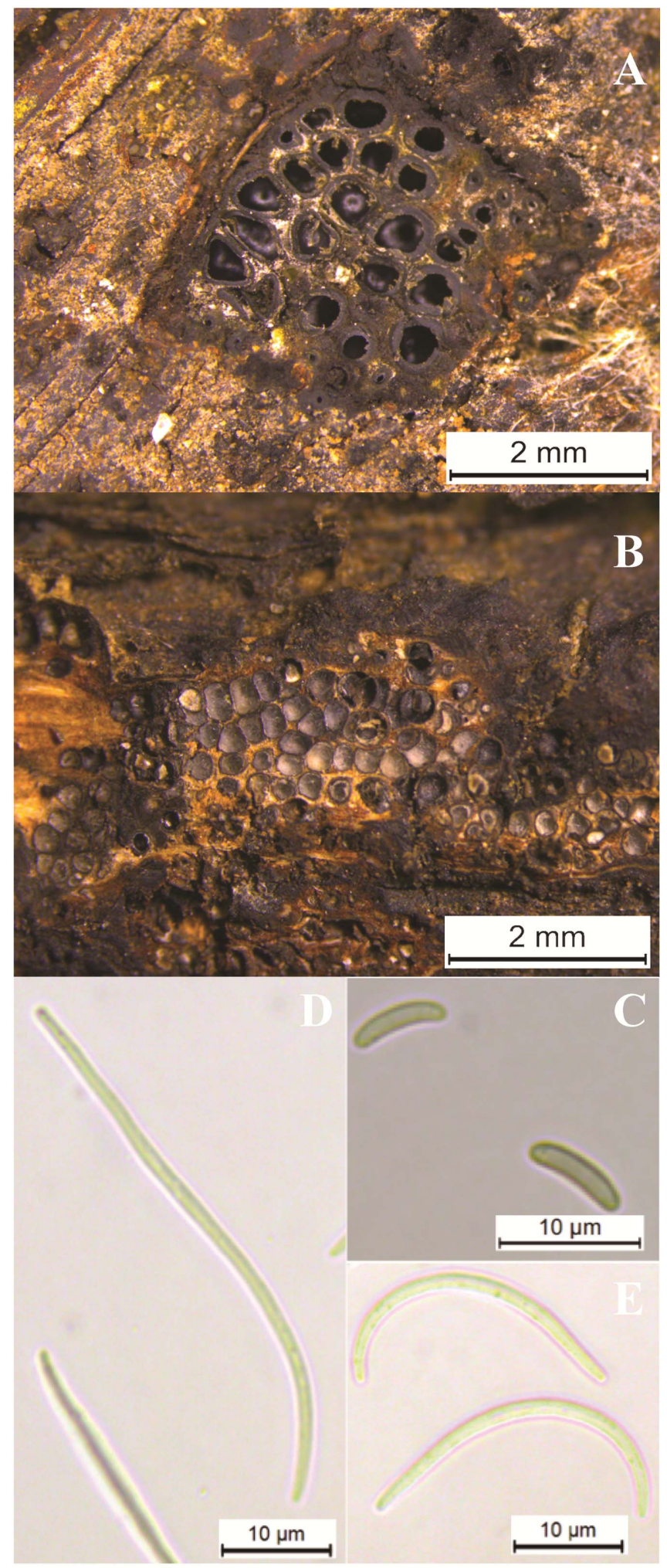

Fig. 3. Dissecting scope and microscope pictures of Eutypa spp. specimens. A, Perithecial stroma of Eutypa lata; B, perithecial stroma of Eutypa sp.; C, E. lata ascospores; D, E. laevata conidia (isolate NYVG2); and E, Eutypa sp. conidia (isolate NYCC1). than E. lata. Perithecial width and ascospore length appear to be useful morphological features to separate Eutypa sp. from E. lata, and conidial length can also be used to separate both species from E. laevata. Rappaz (25) also acknowledged that these traits were useful to distinguish $E$. lata from E. laevata.

Early studies reported the presence of E. armeniacae (syn. E. lata) in Michigan (41) and New York (22). At the time of such reports, the authors relied on the morphology of the field-collected samples and the conidial dimensions of the fungal cultures for species identification. More recently, E. lata was identified in Pennsylvania and Michigan (10), and the identifications were based on the culture morphology and also on ITS rDNA sequences (GenBank accession numbers AY462542 to AY462563). Our findings suggest that separation of E. lata and Eutypa sp. based on anamorphic features is not reliable. Indeed, species misidentification is reported for other taxa within the family Diatrypaeae, in part because of the conflicting taxonomy within this group of fungi $(29,30)$. The identification of E. lata using ITS sequences is confounded by the high percent sequence homology with closely related specimens, as we found with Eutypa sp. and E. laevata. For

Table 3. Conidial length of Eutypa spp. representing type specimens (i.e, CBS208.87 and CBS291.87), voucher specimens (i.e., DCA900 and DSA600), and specimens collected from vineyards with symptoms of Eutypa dieback in eastern North America

\begin{tabular}{llc}
\hline Eutypa spp. & Isolate & Conidia length $(\boldsymbol{\mu m})^{\mathbf{w}}$ \\
\hline Eutypa lata & CBS208.87 & $18-39^{\mathrm{x}}$ \\
E. lata & CBS208.87 & $26.4 \pm 2.3^{\mathrm{y}}$ \\
E. lata & DCA900 & $29.3 \pm 2.3^{\mathrm{z}}$ \\
E. lata & RICRSK1 & $33 \pm 2.6$ \\
E. lata & RICFSK1 & $22.8 \pm 2.4$ \\
E. lata & UCR-EL1 & $33.8 \pm 4.7$ \\
E. lata & M14 & $39.4 \pm 3.1$ \\
Eutypa $\mathrm{sp}$. & CTMF1 & $23.8 \pm 2.2$ \\
Eutypa $\mathrm{sp}$. & NYCC1 & $33 \pm 1.7$ \\
Eutypa $\mathrm{sp}$. & NYCS1 & $21.1 \pm 2.4$ \\
Eutypa $\mathrm{sp}$. & NYDW2 & $22.7 \pm 2.2$ \\
E. laevata & CBS291.87 & $34-55^{\mathrm{x}}$ \\
E. laevata & DSA600 & $54.6 \pm 7.2^{\mathrm{z}}$ \\
E. laevata & NYRT2 & $\ldots$ \\
E. laevata & ONR1 & $\ldots$ \\
E. laevata & NYAR2 & $44.8 \pm 4.7$ \\
E. laevata & NYVG2 & $52.6 \pm 5.8$ \\
\hline Symbol: &
\end{tabular}

${ }^{\mathrm{w}}$ Symbol: ... indicates no conidial dimensions available; isolate did not sporulate in culture.

${ }^{x}$ As reported by Rappaz (24).

y As reported by Rolshausen et al. (28).

${ }^{\mathrm{z}}$ As reported by Trouillas and Gubler (42).

Table 4. Mean lesion length and mean recovery rates of nine Eutypa isolates at 11 months post inoculation in the woody stems of Vitis vinifera 'Chardonnay'x

\begin{tabular}{|c|c|c|c|}
\hline Eutypa spp. & Isolate & $\begin{array}{c}\text { Mean lesion length } \\
(\mathbf{m m})^{\mathrm{y}}\end{array}$ & $\begin{array}{c}\text { Recovery } \\
\text { rate }^{\mathrm{z}}\end{array}$ \\
\hline \multirow[t]{3}{*}{ Eutypa laevata } & NYAR2 & $20(12.6-36.4) \mathrm{B}$ & $0.67 \mathrm{~A}$ \\
\hline & NYRT2 & 15 (10-24.9) B & $0.56 \mathrm{~A}$ \\
\hline & NYVG2 & $13.5(9.2-21.8) \mathrm{A}$ & $0.85 \mathrm{~A}$ \\
\hline \multirow{3}{*}{ Eutypa sp. } & NYCC1 & $18(11.5-31.7) \mathrm{B}$ & $0.84 \mathrm{~A}$ \\
\hline & NYCS1 & $15.6(10.3-26.2) \mathrm{B}$ & $0.87 \mathrm{~A}$ \\
\hline & NYDW2 & $11.3(7.9-17.4) \mathrm{A}$ & $0.71 \mathrm{~A}$ \\
\hline \multirow[t]{3}{*}{ E. lata } & M14 & $27.2(16-56.2) \mathrm{B}$ & $0.62 \mathrm{~A}$ \\
\hline & RICRSK1 & $19.9(12.6-36.1) \mathrm{B}$ & $0.69 \mathrm{~A}$ \\
\hline & RICFSK1 & $16.8(11-28.8) \mathrm{B}$ & $0.87 \mathrm{~A}$ \\
\hline Noninoculated control & $\ldots$ & $7.2(5.4-10.1) \mathrm{A}$ & 0.00 \\
\hline
\end{tabular}

${ }^{x}$ Each value is the mean of 15 observations per experiment and two replicate experiments.

${ }^{y}$ Numbers in parentheses indicate $95 \%$ confidence limits. Means that are significantly greater than the noninoculated control mean are followed by different letters $(P<0.05$; Dunnett's test $)$.

${ }^{\mathrm{z}}$ Means followed by the same letter are not significantly different $(P<$ 0.05; Tukey's test). 
example, we found 94.2 and $95.1 \%$ identity between ITS rDNA sequences of E. lata type specimen CBS208.87 and holotypes of Eutypa sp. isolates NYCC1 (CBS130289) and NYCS1 (CBS130290), respectively. In addition, there was a $96.4 \%$ identity between ITS sequences of the E. lata type specimen CBS208.87 and that of the E. laevata type specimen CBS291.87. Thus, it is possible that the isolates from New York, Michigan, and Pennsylvania that were previously named E. lata $(10,22,41)$ may be more accurately identified as other species according to the criteria we have developed.

Our finding of Eutypa dieback in $65 \%$ of the vineyards examined suggests that this trunk disease is an important component of vineyard decline in eastern North America. In general, the number of diseased vineyards was high in regions with high vineyard density, such as eastern Long Island, NY; the Finger Lakes Region of New York; and the Niagara peninsula of Ontario, Canada. The distribution of E. laevata was restricted to vineyards near Lake Erie, in the states of New York and Ohio and the province of Ontario. Multicordons training provides substrates for formation of Eutypa perithecia because the stroma can form on the dead trunks that were removed because of frost damage (Fig. 4). In fact, this is where we collected the perithecial stroma of Eutypa sp. during our survey. This practice may provide for an inoculum reservoir in aging vineyards, which could explain the higher incidence rate of Eutypa dieback in the older grape production regions in New York and Ontario.

The extremely low frequency (6\% of surveyed vineyards) and scattered distribution of E. lata (i.e., one vineyard in Rhode Island, United States, and two vineyards in Ontario, Canada) are surprising given its cosmopolitan distribution in vineyards (39), its broad host range $(5,9,43)$, and the fact that the $E$. lata isolates we identified were pathogenic on grapevine. One possible explanation is that the reproductive fitness of E. lata is not as well suited as that of Eutypa sp. and E. laevata to some aspects of the climate in eastern North America, such as the extremely low winter temperatures. Alternatively, the region may be outside of the natural range of $E$. lata, and its rarity therein may reflect localized introductions via infected plant material. Human-mediated introduction of grape

Table 5. Percent recovery of Eutypa isolates inoculated to Vitis vinifera 'Chardonnay' (Geneva, NY)

\begin{tabular}{|c|c|c|c|}
\hline \multirow[b]{2}{*}{ Species, isolate } & \multirow[b]{2}{*}{ Inoculation date } & \multicolumn{2}{|c|}{ Recovery (\%) } \\
\hline & & 2009 & 2010 \\
\hline \multicolumn{4}{|l|}{ Control } \\
\hline \multirow[t]{2}{*}{ Noninoculated } & $\mathrm{t}_{0}$ & 0 & 0 \\
\hline & $t_{3}$ & 0 & 0 \\
\hline \multicolumn{4}{|l|}{ Eutypa laevata } \\
\hline \multirow[t]{2}{*}{ NYAR2 } & $t_{0}$ & 0 & 10 \\
\hline & $t_{3}$ & 0 & $6 \mathrm{~ns}$ \\
\hline \multirow[t]{2}{*}{ NYRT2 } & $t_{0}$ & 13 & 0 \\
\hline & $t_{3}$ & $10 \mathrm{~ns}$ & 0 \\
\hline \multicolumn{4}{|l|}{ Eutypa sp. } \\
\hline \multirow[t]{2}{*}{ NYCC1 } & $\mathrm{t}_{0}$ & 23 & 10 \\
\hline & $t_{3}$ & $5 \mathrm{~ns}$ & 0 \\
\hline \multirow[t]{2}{*}{ NYCSPM2 } & $\mathrm{t}_{0}$ & 20 & 5 \\
\hline & $t_{3}$ & $13 \mathrm{~ns}$ & 0 \\
\hline \multirow[t]{2}{*}{ NYCS1 } & $\mathrm{t}_{0}$ & 23 & 10 \\
\hline & $t_{3}$ & $11 \mathrm{~ns}$ & 0 \\
\hline \multirow[t]{2}{*}{ NYDW2 } & $\mathrm{t}_{0}$ & 10 & 5 \\
\hline & $t_{3}$ & $5 \mathrm{~ns}$ & $5 \mathrm{~ns}$ \\
\hline \multicolumn{4}{|l|}{ E. lata } \\
\hline \multirow[t]{2}{*}{ RICFSK1 } & $t_{0}$ & 5 & 5 \\
\hline & $\mathrm{t}_{3}$ & $5 \mathrm{~ns}$ & $5 \mathrm{~ns}$ \\
\hline \multirow[t]{2}{*}{ RICRSK1 } & $\mathrm{t}_{0}$ & 5 & 10 \\
\hline & $t_{3}$ & $10 \mathrm{~ns}$ & $6 \mathrm{~ns}$ \\
\hline
\end{tabular}

${ }^{\mathrm{z}}$ Plants were inoculated on the day of pruning in early April of both years $\left(\mathrm{t}_{0}\right)$ or were inoculated 3 weeks post pruning $\left(\mathrm{t}_{3}\right)$ Recovery attempts were made 6 months following $t_{3}$ in both 2009 and 2010. Each percent recovery value is the mean of four plants, averaged across five pruning wounds per plant; ns indicates that percent recovery at $t_{0}$ and $t_{3}$ are not significantly different $(P>0.05)$ for a given strain within the same year. pathogens and pests is well documented $(6,13,36)$ and the increasing volume of interregional and international commercial trade has enhanced this problem. The history of grape cultivation in the Niagara Peninsula, for example, began in the 19th century with the cultivation of V. labrusca and V. labrusca hybrids such as Concord and 'Catawba' (34). A shift in grape production in the northeastern United States and southwestern Ontario, Canada, toward V. vinifera and Vitis interspecific hybrids began on a small scale after the 1940s but the rapid expansion of such cultivars occurred only in the past 30 years. Relatively recent introductions of E. lata combined with the long incubation period necessary for the fungus to produce ascospores (8) might have limited the spread of the pathogen, thereby restricting its incidence to a few introduction areas. Recent population studies revealed that the distribution of E. lata in several major wine-producing regions worldwide was likely the result of multiple introductions associated with global trade of infected plant material (39), and our results reported herein support this paradigm. Further studies of E. lata populations from eastern North America, and including more isolates, should allow revealing imprints of recent introductions in this region.

All of the three Eutypa spp. identified were pathogenic to Chardonnay in the greenhouse, although there were no characteristic foliar symptoms associated with the disease. However, previous studies showed that several $V$. vinifera cultivars infected with $E$ typa sp. holotype isolate NYCC1 did express typical Eutypa dieback foliar symptoms (40), which supports our field observations of the disease. In addition, pruning wounds of Chardonnay remained susceptible to infection by all of the Eutypa spp. we identified for 3 weeks following pruning in April, which is also supported by previous observations $(22,41)$. This finding is significant because, in the viticulture regions of eastern North America, late winter to early spring is when cold-sensitive grapevine cultivars, such as those of $V$. vinifera, are typically pruned. Trese et al. (41) and Pearson (22) observed that ascospore discharge for isolates of a Eutypa sp. (then referred to as E. armeniacae) from Michigan and New York, respectively, occurs in the winter, hence illustrating the temporal variation in timing of ascospore discharge among Eutypa spp., because E. lata ascospores are mainly released in the fall and spring in Mediterranean regions $(18,24)$. Preventative pruning is the foundation of effective management for Eutypa dieback in California (47); therefore, the efficacy of similar measures in eastern North America will depend on a clear understanding of the timing the ascospore discharge for the different Eutypa spp. and how this coincides with the period of susceptibility of grapevine pruning wounds. In addition, Eutypa dieback management may better be achieved with wound protection following pruning and trunk removal. Post-pruning application of thiophanate-methyl

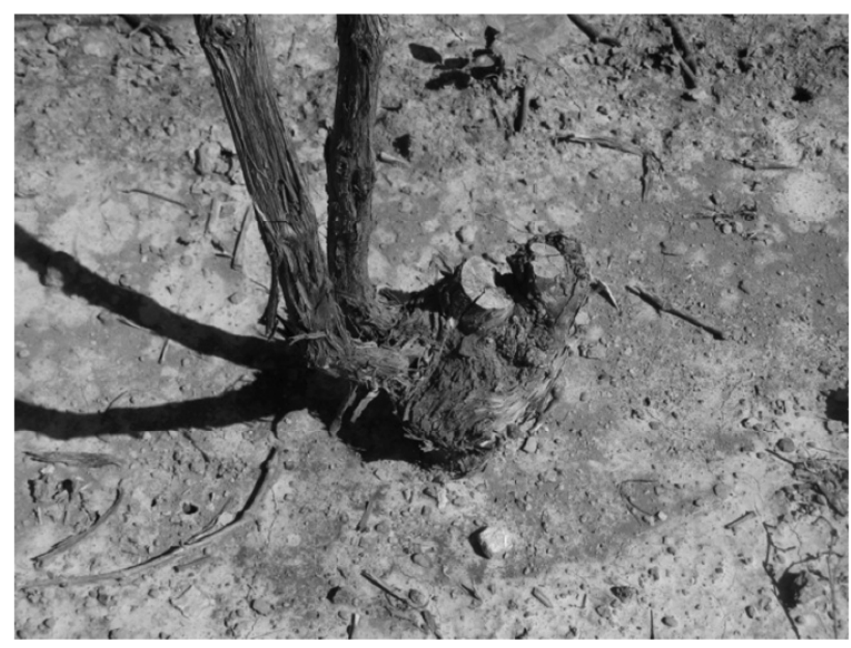

Fig. 4. Cultural practice known as trunk renewal, which consists of training new trunks and removing old ones that were likely killed by cold temperature. This picture shows two newly trained trunks and two that were previously removed. 
has proven to be a very effective practice in California for control of Eutypa dieback (31). This product is also registered in New York, and growers may consider implementing this practice in order to limit the establishment of this devastating disease and extend the lifespan of their vineyards.

\section{Acknowledgments}

Research was funded by grant number 2008-51100-19334 to K. Baumgartner and P. E. Rolshausen from the USDA, National Institute of Food and Agriculture. We thank B. Mackey (Statistician, USDA-ARS, Albany, CA) for advice on statistical analyses; A. Schilder (Michigan State University), M. Ellis (Ohio State University), and W. McFadden-Smith (Ontario Ministry of Agriculture) for their assistance; vineyard owners for access to field sites; and the Foundation Plant Services in Davis, CA, for the donation of grapevine cuttings.

\section{Literature Cited}

1. Acero, F. J., Gonzalez, V., Sanchez-Ballesteros, J., Rubio, V., Checa, J., Bills, G. F., Salazar, O., Platas, G., and Pelaez, F. 2004. Molecular phylogenetic studies on the Diatrypaceae based on rDNA-ITS sequences. Mycologia 96:249-259.

2. Baumgartner, K., Bergemann, S. E., Fujiyoshi, P., Rolshausen, P. E., and Gubler, W. D. 2009. Microsatellite markers for the grapevine pathogen, $\mathrm{Eu}$ typa lata. Mol. Ecol. Resour. 9:222-224.

3. Baumgartner, K., Fujiyoshi, P. T., Travadon, R., Castlebury, L. A., Wilcox, W. F., and Rolshausen, P. E. 2013. Characterization of species of Diaporthe from wood cankers of grape in eastern North American vineyards. Plant Dis. 97:912-920.

4. Blanco-Ulate, B., Rolshausen, P. E., and Cantu, D. 2013. Draft genome sequence of the grapevine dieback fungus Eutypa lata UCR-EL1. Genome Announcement 1:e00228-13.

5. Bolay, A., and Carter, M. V. 1985. Newly recorded hosts of Eutypa lata synonym Eutypa armeniacae in Australia. Plant Prot. Quarantine 1:10-12.

6. Brewer, M. T., and Milgroom, M. G. 2010. Phylogeography and population structure of the grape powdery mildew fungus, Erysiphe necator, from diverse Vitis species. BMC Evol. Biol. 10:268-280.

7. Carter, M. V. 1957. Eutypa armeniacae. Aust. J. Bot. 5:21.

8. Carter, M. V. 1991. The status of Eutypa lata as a pathogen. In: Monogr. Phytopathol. Pap. No. 32. International Mycological Institute, Surrey, UK.

9. Carter, M. V., Bolay, A., and Rappaz, F. 1983. An annotated list and bibliography of Eutypa armeniacae. Rev. Plant Pathol. 62:251-258.

10. Catal, M., Jordan, S. A., Butterworth, S. C., and Schilder, A. M. C. 2007. Detection of Eutypa lata and Eutypella vitis in grapevine by nested multiplex polymerase chain reaction. Phytopathology 97:737-747.

11. Felsenstein, J. 1985. Confidence-limits on phylogenies - an approach using the bootstrap. Evolution 39:783-791.

12. Glass, N. L., and Donaldson, G. C. 1995. Development of primer sets designed for use with the PCR to amplify conserved genes from filamentous ascomycetes. Appl. Environ. Microbiol. 61:1323-1330.

13. Granett, J., Walker, M. A., Kocsis, L., and Omer, A. D. 2001. Biology and management of grape phylloxera. Annu. Rev. Entomol. 46:387-412.

14. Littell, R. C., Milliken, G. A., Stroup, W. W., Wolfinger, R. D., and Schabenberger, O. 2003. SAS for Mixed Models. SAS Institute Inc., Cary, NC.

15. Liu, Y. J. J., Whelen, S., and Benjamin, D. H. 1999. Phylogenetic relationships among ascomycetes: evidence from an RNA polymerase II subunit. Mol. Biol. Evol. 16:1799-1808.

16. Mahoney, N., Molyneux, R. J., Smith, L. R., Schoch, T. K., Rolshausen, P. E., and Gubler, W. D. 2005. Dying-arm disease in grapevines: diagnosis of infection with Eutypa Iata by metabolite analysis. J. Agric. Food Chem. 53:8148-8155

17. Moller, W. J., Braun, A. J., Uyemoto, J. K., and Kasimatis, A. N. 1977. Eutypa armeniacae inoculum associated with dead arm-affected grapevines in New-York and Ontario. Plant Dis. Rep. 61:422-423.

18. Moller, W. J., and Carter, M. V. 1965. Production and Dispersal of Ascospores in Eutypa Armeniacae. Aust. J. Biol. Sci. 18:67.

19. Mostert, L., Halleen, F., Creaser, M. L., and Crous, P. W. 2004. Cryptovalsa ampelina, a forgotten shoot and cane pathogen of grapevines. Australas. Plant Pathol. 33:295-299.

20. Munkvold, G. P., Duthie, J. A., and Marois, J. J. 1994. Reductions in yield and vegetative growth of grapevines due to Eutypa dieback. Phytopathology 84:186-192.

21. Octave, S., Roblin, G., Vachaud, M., and Fleurat-Lessard, P. 2006. Polypeptide metabolites secreted by the fungal pathogen Eutypa lata participate in Vitis vinifera cell structure damage observed in Eutypa dieback. Funct. Plant Biol. 33:297-307.

22. Pearson, R. C. 1980. Discharge of ascospores of Eutypa armeniacae in New York. Plant Dis. 64:171-174.

23. Peros, J. P., and Berger, G. 2003. Genetic structure and variation in aggres- siveness in European and Australian populations of the grapevine dieback fungus, Eutypa lata. Eur. J. Plant Pathol. 109:909-919.

24. Ramos, D. E., Moller, W. J., and English, H. 1975. Production and Dispersal of Ascospores of Eutypa armeniacae in California. Phytopathology 65:1364-1371.

25. Rappaz, F. 1987. Taxonomie et nomenclature des Diatrypacées à asques octosporées. Mycol. Helv. 2:285-648

26. Rolshausen, P., Baumgartner, K., Bergemann, S., Fujiyoshi, P., Gubler, D., and Wilcox, W. 2008. Geographical diversity of the grapevine pathogen $\mathrm{Eu}$ typa lata in North American vineyards. (Abstr.) Phytopathology 98:S135.

27. Rolshausen, P. E., Greve, L. C., Labavitch, J. M., Mahoney, N. E., Molyneux, R. J., and Gubler, W. D. 2008. Pathogenesis of Eutypa lata in grapevine: identification of virulence factors and biochemical characterization of cordon dieback. Phytopathology 98:222-229.

28. Rolshausen, P. E., and Gubler, W. D. 2005. Use of boron for the control of Eutypa dieback of grapevines. Plant Dis. 89:734-738.

29. Rolshausen, P. E., Mahoney, N. E., Molyneux, R. J., and Gubler, W. D. 2006. Reassessment of the species concept in Eutypa lata, the causal agent of Eutypa dieback of grapevine. Phytopathology 96:369-377.

30. Rolshausen, P. E., Trouillas, F., and Gubler, W. D. 2004. Identification of Eutypa lata by PCR-RFLP. Plant Dis. 88:925-929.

31. Rolshausen, P. E., Urbez-Torres, J. R., Rooney-Latham, S., Eskalen, A., Smith, R. J., and Gubler, W. D. 2010. Evaluation of pruning wound susceptibility and protection against fungi associated with grapevine trunk diseases. Am. J. Enol. Viticult. 61:113-119.

32. Rolshausen, P. E., and Wilcox, W. 2009. Identifying the causes of wood cankers and branch dieback in eastern US vineyards. Phytopathol. Mediterr 48:164-164.

33. Saitou, N., and Nei, M. 1987. The neighbor-joining method-a new method for reconstructing phylogenetic trees. Mol. Biol. Evol. 4:406-425.

34. Shaw, A. B. 2005. The Niagara Peninsula viticultural area: a climatic analysis of Canada's largest wine region. J. Wine Res. 16:85-103.

35. Siebert, J. B. 2001. Eutypa: The economic toll on vineyards. Page 6 in: Wines \& Vines.

36. Smetham, G. M., Ades, P. K., Peros, J. P., and Ford, R. 2010. Genetic structure of the grapevine fungal pathogen Phaeomoniella chlamydospora in southeastern Australia and southern France. Plant Pathol. 59:736-744.

37. Tamura, K., and Nei, M. 1993. Estimation of the number of nucleotide substitutions in the control region of mitochondrial-DNA in humans and chimpanzees. Mol. Biol. Evol. 10:512-526.

38. Tamura, K., Peterson, D., Peterson, N., Stecher, G., Nei, M., and Kumar, S. 2011. MEGA5: molecular evolutionary genetics analysis using maximum likelihood, evolutionary distance, and maximum parsimony methods. Mol. Biol. Evol. 28:2731-2739.

39. Travadon, R., Baumgartner, K., Rolshausen, P. E., Gubler, W. D., Sosnowski, M. R., Lecomte, P., Halleen, F., and Peros, J. P. 2012. Genetic structure of the fungal grapevine pathogen Eutypa lata from four continents. Plant Pathol. 61:85-95.

40. Travadon, R., Rolshausen, P. E., Gubler, W. D., Cadle-Davidson, L., and Baumgartner, K. 2013. Susceptibility of cultivated and wild Vitis to wood infection by fungal trunk pathogens. Plant Dis. 97:1529-1536.

41. Trese, A. T., Burton, C. L., and Ramsdell, D. C. 1980. Eutypa armeniacae in Michigan vineyards - ascospore production and survival, host infection, and fungal growth at low temperatures. Phytopathology 70:788-793.

42. Trouillas, F. P., and Gubler, W. D. 2004. Identification and characterization of Eutypa leptoplaca, a new pathogen of grapevine in Northern California. Mycol. Res. 108:1195-1204.

43. Trouillas, F. P., and Gubler, W. D. 2010. Host range, biological variation, and phylogenetic diversity of Eutypa lata in California. Phytopathology 100:1048-1056.

44. Trouillas, F. P., Pitt, W. M., Sosnowski, M. R., Huang, R. J., Peduto, F., Loschiavo, A., Savocchia, S., Scott, E. S., and Gubler, W. D. 2011. Taxonomy and DNA phylogeny of Diatrypaceae associated with Vitis vinifera and other woody plants in Australia. Fungal Divers. 49:203-223.

45. Trouillas, F. P., Urbez-Torres, J. R., and Gubler, W. D. 2010. Diversity of diatrypaceous fungi associated with grapevine canker diseases in California. Mycologia 102:319-336.

46. Urbez-Torres, J. R., Leavitt, G. M., Voegel, T. M., and Gubler, W. D. 2006 Identification and distribution of Botryosphaeria spp. associated with grapevine cankers in California. Plant Dis. 90:1490-1503.

47. Weber, E. A., Trouillas, F. P., and Gubler, W. D. 2007. Double pruning of grapevines: A cultural practice to reduce infections by Eutypa lata. Am. J. Enol. Viticult. 58:61-66

48. White, T. J., Bruns, T., Lee, S., and Taylor, J. 1990. Amplification and direct sequencing of fungal ribosomal RNA genes for phylogenetics. Pages 315 322 in: PCR Protocols, A Guide to Methods and Applications. M. A. Innis, D. H. Gelfand, J. J. Sninsky, and T. J. White, eds. Academic Press, San Diego, CA. 